\title{
An approach to mathematical models as a tool for water and air quality management
}

\section{D.R. Khanna, R. Bhutiani* and Neetu Saxena}

Department of Zoology and Environmental Science, Gurukula Kangri University, Haridwar-249404 (UK), INDIA *Corresponding author. E-mail: rbhutiani@gmail.com

Received: May 3, 2014; Revised received: May 28, 2014; Accepted: June 17, 2014

Abstract: Interactions between mathematical and biological sciences have been increasing rapidly in recent years. The use of system analysis and mathematical model for formulation and solving the environmental pollution is of relatively recent vintage and has been used widely since last three decades. These models can be used to conduct numerical experiments, test hypothesis and help to understand the response of environmental pollution. A mathematical model acts as a bridge between study of mathematics and application of mathematics in environment and other fields. Modeling is an abstraction of reality and its ultimate objective is to explore the complexity of functions and structure of the system under study. Today, a wide variety of models belonging to different nature and category are available to understand the processes of the environment around us. Various models such as WASP, CE-QUAL-ICM, QUAL W2, AQUATOX, QUAL2K, IITAQ, PEARL, GRAM, UGEM, and IITLT etc. related to water and air quality are developed so far along with their principles, intended use and applications. These models generally simulate the basic physical, chemical and biological processes. In the present study, an attempt has been made to evaluate the concept and utilization of mathematical models in air and water quality management.

Keywords: Assessment, Environmental quality, Limnology, Mathematical models

\section{INTRODUCTION}

The development of the mathematical models is a logical development of earlier descriptive tools used to analyse the environment such as drawings, classification and maps. Models should be seen as a complement to other techniques used to arrive at an understanding and they also, we believe uniquely, provide an important means of testing our understanding (Wainwright and Mulligan, 2004). Models can thus be used to evaluate whether the effects and outcomes are reproducible from the current knowledge of the processes or not. In the present study an attempt has been made to discuss some of the important models developed so far related to water and air quality. The present study gives a brief introduction of some of these models along with their principles, intended use and application in the real world situation.

Water quality modeling: Mathematical models have been developed since the origin of mathematics, but there was a significant increase in modeling activity since the development of calculus by Newton and Leibniz working independently in the second half of the seventeenth century. In the past few decades, many researchers have studied water quality characteristics of water bodies using numerical models (Cerco and Cole, 1993; Jin et al., 1998; Gin et al., 2001). These models generally simulate the basic physical, chemical and biological processes of the aquatic ecosystems.

The most commonly reported causes of impairment in rivers and streams are pathogens, siltation, habitat alterations, oxygen-depleting substances, nutrients, thermal modifications, metals and flow alterations; in lakes and reservoirs the primary cause includes nutrients, metals, siltation, total dissolved solids, oxygen-depleting substances, excess algal growth and pesticides (Park et al., 2004). The most commonly reported sources of impairment are agriculture, hydrologic modifications, habitat modification, urban runoff/storm sewers, forestry, non-point sources, municipal point sources, atmospheric deposition, resource extraction and land disposal. For that there are requirements for new approaches and tools, including appropriate technical guidance documents that facilitate water quality and ecological analyses. In particular, there is a pressing need for refinement and release of an ecological risk methodology that addresses the direct, indirect, and synergistic effects of nutrients, metals, toxic organic chemicals and non chemical stressors on aquatic ecosystems, including streams, rivers, lakes and estuaries. Some of the more important phenomenon for water quality system modeling is equilibrium relationships, diffusion theory, exponential law, gas law, conservation equations for mass, momentum and energy balances (Kuzmin, 2010). 
Each one of the water quality variables can be described by the following equation:

Equation for mass/energy balance: A basic principle for both hydrodynamics and river water quality models is the conservation of mass. The hydrodynamic model also follows the principle of momentum andlor energy conservation. The most general equation for the conservation of mass is

$$
\frac{d}{d t}(m)=\sum\left(m_{\text {in }}\right)-\sum\left(m_{\text {out }}\right)
$$

The time derivative portion represents the change in the mass within the system. The two summations represent the inflow and outflow of mass.

A mass balance equation in aquatic system must account for input mass and output through direct and diffuse loading, adjective and dispersive transport and physical, chemical and biological transformation. When we conceded an equation with $\mathrm{x}$ - coordinate in longitudinal plane $y$ - coordinate in lateral plane and $\mathrm{z}$ - coordinate in the vertical plane.

$$
\frac{\partial C_{i}}{\partial t}+\frac{\partial\left(U C_{i}\right)}{\partial x}+\frac{\partial\left(V C_{i}\right)}{\partial y}+\frac{\partial\left(W C_{i}\right)}{\partial z}=\frac{\partial}{\partial x}\left(D_{x} \frac{\partial C_{i}}{\partial x}\right)+\frac{\partial}{\partial y}\left(D_{y} \frac{\partial C_{i}}{\partial y}\right)+\frac{\partial}{\partial z}\left(D_{z} \frac{\partial C_{i}}{\partial z}\right)+\sum S_{i}
$$

In which $U, V, W$ are the water velocity components in longitudinal $(x)$, lateral $(y)$ and vertical $(z)$ directions, respectively; $C i$ is the concentration of the $i^{\text {th }}$ water quality constituent; $D x, D y$ and $D z$ are the diffusion coefficients in $x, y$ and $z$ directions respectively; $\sum S i$ is the effective source term, which includes the kinetic transformation rate, external loads and sinks for $i^{\text {th }}$ water quality constituent.

Non-conservative substance transport - steady state condition: In a steady state model, all flows, loadings, and other inputs are assumed to be constant over time. In addition, all kinetics is assumed to be constant over the time. Most of the steady state models do allow spatial variations in flow, loads, other inputs and kinetics. Most steady state models are one-dimensional with respects to space, and calculate variation of concentration with distance, predicting variations in concentration in only one dimension, usually upstream to downstream and assuming complete mixing across the cross section area (Thomann and Mueller,1988).

The numerical model for predicting concentration of a non-conservative substance in a 1-dimensional river flow with concentration, depth and velocity. Under the steady state conditions, the concentration of the substance can be expressed as:

$$
U \frac{\partial C}{\partial x}=D_{x} \frac{\partial^{2} C}{\partial x^{2}}-K C
$$

Analytical solution given by Thomann and Mueller (1988) is:

$$
\begin{array}{ccc}
C(x)= & C_{0} \exp \left[\left(\frac{U+\sqrt{U^{2}+4 K D_{x}}}{2 D_{x}}\right) x\right](\text { upstream }, x \leq 0) \\
U & : & \text { Velocity } \\
C & : & \text { Substance concentration } \\
C_{0} & : & \text { Initial nutrient concentration at each }
\end{array}
$$

$\begin{array}{lll} & & \text { time step in the solution } \\ D x & : & \text { Dispersion coefficient } \\ x & : & \text { Displacement from O point, and } \\ K & : & \text { Decay rate }\end{array}$

Non-conservative substance transport - unsteady state condition: A dynamic model allows variations over space and time flows, loadings and other inputs, and sometimes kinetics. They are often two or three-dimensional models with respect to space, allowing variation in simulated results for longitudinal, laterally and with depth. Results from a dynamic model also vary in both space and time (Chapra, 1997).

The hypothetical case involves a river as in the first case, but with a continuous source of a non-conservative substance for a finite period of time,

$\tau$. The mass transport equation for this case is:

$\frac{\partial C}{\partial t}+U \frac{\partial C}{\partial x}=D_{x} \frac{\partial^{2} C}{\partial x^{2}}-K C$

Chapra (1997) gave an analytical solution for this case:

$$
\begin{aligned}
& C(x, t)=\frac{C_{0}}{2}\left[\exp \left(\frac{U x}{2 D_{x}}(1-\Gamma)\right) \operatorname{erfc}\left(\frac{x-U t \Gamma)}{2 \sqrt{D_{x} t}}\right)+\exp \left(\frac{U x}{2 D_{x}}(1+\Gamma)\right) \operatorname{erfc}\left(\frac{x+U t \Gamma}{2 \sqrt{D_{x} t}}\right)\right](t<\tau) \\
& C(x, t)=\frac{C_{0}}{2}\left\{\begin{array}{l}
\exp \left(\frac{U x}{2 D_{x}}(1-\Gamma)\right)\left[\operatorname{erfc}\left(\frac{x-U t \Gamma}{2 \sqrt{D_{x} t}}\right)-\operatorname{erfc}\left(\frac{x-U(t-\tau) \Gamma}{2 \sqrt{D_{x}(t-\tau)}}\right)\right] \\
\left.+\exp \left(\frac{U x}{2 D_{x}}(1+\Gamma)\right)\left[\operatorname{erfc}\left(\frac{x+U t \Gamma}{2 \sqrt{D_{x} t}}\right)-\operatorname{erfc}\left(\frac{x+U(t-\tau) \Gamma}{2 \sqrt{D_{x}(t-\tau)}}\right)\right]\right\}(t>\tau)
\end{array}\right.
\end{aligned}
$$

Where:

$$
\begin{aligned}
& \Gamma=\sqrt{1+4 \eta} \\
& \begin{array}{l}
\tau \\
\eta=\frac{K D_{x}}{U^{2}}
\end{array} \\
& \quad: \text { a finite time period } \\
& \begin{array}{l}
U \quad \text { : velocity } \\
C \quad \text { substance concentration; }
\end{array}
\end{aligned}
$$

$C_{0}$

: initial nutrient concentration at each time step in the solution.

Dx : dispersion coefficient;

$x \quad$ :displacement from $O$ point; and

$K \quad$ : decay rate.

erfc : error function complement

Water quality models

Water quality indices (WQI) (Conesa Fdez-Vitora, 1995): The use of water quality indices (WQI) is a simple method to receive water quality information. WQI also permits us to assess changes in the water quality and to identify water trends (Chapman, 1992). A quality index is a unitless number that ascribes a quality value to an aggregate set of measured parameters. The construction of WQI requires first a normalization step, where each parameter is transformed into a $0-100 \%$ scale, with 100 representing the highest quality. The next step is to apply weighting factors that reflect the importance of each parameter as indicators of the water quality 
(Boler, 1992; Conesa Fdez-Vitora, 1995). The required environmental parameters for WQI are sulfates, ammonia, BOD, calcium, COD, DO, chloride, hardness, magnesium, nitrates, $\mathrm{pH}$, nitrites, TSS, TS, TDS, surfactants, temperature, total coliforms, turbidity and the governing equation of WQI is as follows:

$$
W Q I_{\text {sub }}=k \frac{\sum_{i} C_{i} x P_{i}}{\sum_{i} P_{i}}
$$

$\mathrm{k}$ : Subjective constant and it represents the visual impression of river contamination

$\mathrm{X}$ : assigned parameter

$\mathrm{C}_{\mathrm{i}}$ : value assigned to each parameter after normalization;

$\mathrm{P}_{\mathrm{i}}$ : relative weight assigned to each parameter. $\left(\mathrm{P}_{\mathrm{i}}\right.$ value range from 1 to 4 , with 4 representing a parameter that has most importance for aquatic life preservation. While a value of 1 means that such parameter has a smaller impact).

2-D Hydraulic model RMA-2V (King, 1990): RMA-2V, originally developed by King (1990) and now maintained by the Army Corps of Engineers Waterways Experiment Station. RMA-2V is a two dimensional finite element program that uses the Galerkin method of weighted residuals and a Newton- Raphson scheme to solve the shallow water equation. Linear shape functions are used for depth and quadratic shape functions for velocity. The shallow water equations consist of an equation for conservation of mass and two equations for the conservation of momentum in horizontal directions.

$$
\begin{aligned}
& \frac{\partial h}{\partial t}+\frac{\partial}{\partial x}(h u)+\frac{\partial}{\partial y}(h v)=0 \\
& \frac{\partial u}{\partial t}+u \frac{\partial u}{\partial x}+v \frac{\partial u}{\partial y}+g\left(\frac{\partial h}{\partial x}+\frac{\partial z_{0}}{\partial x}\right)-\frac{\epsilon_{x x}}{\rho} \frac{\partial^{2} u}{\partial x^{2}}-\frac{\epsilon_{x y}}{\rho} \frac{\partial^{2} u}{\partial y^{2}}+\frac{g u}{C^{2} h} \sqrt{u^{2}+v^{2}}=F_{x} \\
& \frac{\partial v}{\partial t}+u \frac{\partial v}{\partial x}+v \frac{\partial v}{\partial y}+g\left(\frac{\partial h}{\partial y}+\frac{\partial z_{0}}{\partial y}\right)-\frac{\epsilon_{y x}}{\rho} \frac{\partial^{2} v}{\partial x^{2}}-\frac{\epsilon_{y y}}{\rho} \frac{\partial^{2} v}{\partial y^{2}}+\frac{g v}{C^{2} h} \sqrt{u^{2}+v^{2}}=F_{y} \\
& \mathrm{x} \text { and } \mathrm{y} \quad \text { : cartesian coordinates in a hori } \\
& \text { zontal plane; } \\
& \mathrm{u} \text { and } \mathrm{v} \quad \text { : depth averaged velocity in the } \mathrm{x} \\
& \text { and y directions } \\
& \begin{array}{ll}
\mathrm{t} & : \text { time } \\
\mathrm{h} & : \text { water depth }
\end{array} \\
& e_{x x}, e_{x y}, e_{y x} \text { and } e_{y y} \text { : eddy viscosity coefficients; } \\
& \text { C : chezy coefficient } \\
& \text { g : gravity } \\
& \mathrm{r} \quad \text { : fluid density } \\
& \mathrm{z}_{0} \quad \text { : channel bottom elevation } \\
& \mathrm{F}_{\mathrm{x}} \text { and } \mathrm{F}_{\mathrm{y}} \quad \text { : optional terms incorporating cori } \\
& \text { olis and wind forces acting in the } \\
& \mathrm{x} \text { and } \mathrm{y} \text { direction. }
\end{aligned}
$$

The Reynolds averaged transient Navier-Stokes Equations (Reynolds, 1984): Model is based upon the Navier-Stokes equations divided into three parts; the first term on the left-hand side of the equation is the transient term. An implicit method was used to model this term. The next term on the left-hand side is the convective term. This was solved using a first -order upwind method. The pressure term on the right-hand side was solved by using the SIMPLE method (Patankar, 1980). The last term is the Reynolds stress term, which was modeled using the eddy- viscosity concept. This model is a part of hydrodynamicbiological model made for prediction of main features of the spatial distribution of phytoplankton in the reservoir with a reasonable degree of success. This model is mainly used for the calculation of water flow of stream and river.

$$
\frac{\partial U_{i}}{\partial t}+U_{i} \frac{\partial U_{i}}{\partial x_{i}}=\frac{1}{\rho} \frac{\partial}{\partial x_{j}}\left(-P \delta_{v}-\overline{\rho u_{i} u_{i}}\right)
$$

$\begin{array}{lll}\mathrm{U}_{\mathrm{i}} & : & \text { velocity averaged over a time step } \\ \mathrm{X}_{\mathrm{i}} & : & \text { space variable } \\ \mathrm{P} & : & \text { pressure } \\ \mathrm{r} & : & \text { water density } \\ \mathrm{d}_{\mathrm{q}} & : & \text { kronecker delta } \\ \mathrm{u}_{\mathrm{i}} & : & \text { turbulent fluctuation of the velocity } \\ & & \text { around the average. }\end{array}$

Box scheme (One dimensional kinematics wave equation) (Wood and Arnold, 1990): Wood and Arnold (1990) gave the one-dimensional kinematic wave equation for small inertial effects. The box scheme is mainly used for hydraulic behavior of overland flow, caused by rainfall-runoff on a sloping plane. It is also used for the numerical solution of the one-dimensional kinematics wave equations.

$$
\begin{aligned}
& (1-\theta) \frac{q_{i}^{k+1}-q_{i}^{k}}{\Delta t}+\theta \frac{q_{i+1}^{k+1}-q_{i+1}^{k}}{\Delta t}+(1-\omega) u(\bar{q})\left[\frac{q_{i+1}^{k}-q_{i}^{k}}{\Delta x}-Q_{r}\right]+\omega u\left(\stackrel{-}{q}^{k+1}\right)\left[\frac{q_{q_{i+1}^{k+1}}^{k} q_{i}^{k+1}}{\Delta x}-Q_{r}\right]=0 \\
& u\left(\begin{array}{c}
-k \\
q
\end{array}\right)=\frac{\left[\frac{q_{i}^{k}+q_{i+1}^{k}}{2}\right]^{215}}{n^{315}} S_{o x}^{3110} \\
& u(\bar{q})=\frac{q^{2 \backslash 5} S_{o x}^{3 \backslash 10}}{n^{315}} \\
& \mathrm{k} \quad \text { : } \quad \text { surface mass transfer coefficient } \\
& \text { u : mean velocity } \\
& \mathrm{S}_{\mathrm{ox}} \quad \text { : } \quad \text { bed slope in the x-direction } \\
& \mathrm{Q}_{\mathrm{r}} \quad \text { : } \quad \text { rainfall intensity }\left(\mathrm{m} / \mathrm{sec}^{2}\right) \\
& \text { q : } \quad \text { discharge per unit width } \\
& \text { i : } \quad \text { spatial node numbers in the } \mathrm{x}- \\
& \text { direction } \\
& \text { n : manning roughness coefficient }
\end{aligned}
$$

The term $\mathrm{u}\left(\mathrm{q}^{\mathrm{k}+1}\right)$ corresponds to the term in equation 1 advanced by one time step.

The two weighting parameters $\mathrm{q}$ and $\mathrm{w}$ are used to improve numerical stability. Both $\mathrm{q}$ and $\mathrm{w}$ were set 0.5 .

Computational fluid dynamics (CFD) (Versteeg and Malalasekera, 1995): In general CFD is taken to imply a full three- dimensional calculation of a fully turbulent flow field. CFD is based on solving the physical laws of conservation of mass and Newton's 2nd Law as applied to a fluid and these are encapsulated in the Navier-Stokes equations for incompressible flow. The first equation encapsulates conservation of mass, second is a momentum equation where the first term is the time variation and the 
second is the convection term: on the right- hand side the term are, respectively, a pressure gradient, a diffusion term and source term i.e. corilis force, wind shear, gravity . The applications of this model are very extensive, in river, estuarine and coastal area. The CFD can also be used for analyzing flows at small-scale river works such as sluice gates, weirs, outfalls and fish passes (Rodriguez et al., 2001).

$$
\begin{aligned}
& \frac{\partial u_{i}}{\partial x_{i}}=0 \\
& \frac{\partial\left(\rho u_{i}\right)}{\partial t}+\frac{\partial\left(\rho u_{i} u_{j}\right)}{\partial x_{j}}=-\frac{\partial P}{\partial x_{i}}+\frac{\partial}{\partial x_{j}}\left(\mu \frac{\partial u_{i}}{\partial x_{j}}\right)+S_{i}
\end{aligned}
$$

$\begin{array}{lll}\mathrm{x}_{\mathrm{i}} & : & \text { the three coordinate directions } \\ \mathrm{u}_{\mathrm{i}} & : & \text { velocities in these directions } \\ \mathrm{p} & : & \text { pressure } \\ \mathrm{r} & : & \text { density } \\ \mathrm{m} & : & \text { viscosity } \\ S_{i} & : & \text { the effective source term }\end{array}$

The exposure analysis modeling system (EXAMS) (Lawrence, 2004): EXAMS is a set of process modules that links fundamental chemical properties to the limnological parameters. It controls the kinetics of fate and transport in aquatic systems. The EXAMS program is a deterministic, rather than a stochastic, model based on a core of mechanistic process equations derived from fundamental theoretical concepts i.e. at given set of inputs it will always produce the same output. EXAMS provides facilities for steady-state analysis of chronic chemical discharges, initial value approaches for study of short-term chemical releases, and full kinetic simulations that allow for monthly variation in mean climatologically parameters and alteration of chemical loadings on daily time scales.

$$
\begin{aligned}
& V \frac{d[C]}{d t}=L e+L i-V K[C] \\
& V \quad: \quad \text { volume of water in the compartment } \\
& \text { [C] : } \quad \text { (liters), } \\
& \text { Le : } \quad \text { liter of } V \text {, } \\
& \text { Li : } \quad \text { compartment }(\mathrm{mg} / \mathrm{h}) \text {, }
\end{aligned}
$$

Hydrodynamic and water quality river basin modeling (CE-QUAL-W2): CE-QUAL-W2 is a two- dimensional, longitudinallvertical, hydrodynamic and water quality model developed by the Waterways Experiment Station (WES). Because the model assumes lateral homogeneity, it is best suited for relatively long and narrow water bodies exhibiting longitudinal and vertical water quality gradients. CE-QUAL-W2 V3 an advance version for CE-QUALW2 V2 (Cole and Buchak, 1995) has been widely applied to stratified surface water systems such as lakes, reservoirs, and estuaries and computes water levels, horizontal and vertical velocities, temperature, and 21 other water quality parameters (such as dissolved oxygen, nutrients, organic matter, algae, $\mathrm{pH}$, the carbonate cycle, bacteria, and dissolved and suspended solids etc.). Version 3 has the capability of modeling entire river basins with rivers and inter-connected lakes, reservoirs, and estuaries. Basic governing equations for this model are shown below:

X- momentum:

$$
\frac{\partial U B}{\partial t}+\frac{\partial U U B}{\partial x}+\frac{\partial W U B}{\partial z}=g B \sin \alpha+g \cos \alpha B \frac{\partial \eta}{\partial x}-\frac{g \cos \alpha B}{\rho} \int_{\eta}^{z} \frac{\partial \rho}{\partial x} \partial z+\frac{1}{\rho} \frac{\partial B \tau_{x x}}{\partial x}+\frac{1}{\rho} \frac{\partial B \tau_{x z}}{\partial z}+q B U_{x}
$$

\section{Z-momentum:}

$$
0=g \cos \alpha-\frac{1}{\rho} \frac{\partial P}{\partial z}
$$

Free surface Equation:

$$
B_{\eta} \frac{\partial \eta}{\partial t}=\frac{\partial}{\partial x} \int_{\eta}^{h} U B d_{z}-\int_{\eta}^{h} q B d_{z}
$$

\section{Equation of State:}

$$
\rho=f\left(T_{w}, \phi_{T D S}, \phi_{s s}\right)
$$

\section{Conservation of mass/heat:}

$$
\frac{\partial B \phi}{\partial t}+\frac{\partial U B \phi}{\partial x}+\frac{\partial W B \phi}{\partial z}-\frac{\partial\left[B D_{x} \frac{\partial \phi}{\partial x}\right]}{\partial x}-\frac{\partial\left[B D_{z} \frac{\partial \phi}{\partial z}\right]}{\partial z}=q_{\phi} B+S_{\phi} B
$$

$\mathrm{U}, \mathrm{W} \quad$ : $\quad$ horizontal and vertical velocity,

B : channel width,

P : $\quad$ pressure,

g : : acceleration due to gravity,

$\mathrm{t}_{\mathrm{x}}, \mathrm{t}_{\mathrm{z}} \quad$ : $\quad$ lateral average shear stress in $\mathrm{x}$ and $\mathrm{z}$

$r \quad: \quad$ density

h : $\quad$ water surface

a : channel angle,

$\mathrm{U}_{\mathrm{x}} \quad$ : $\quad \mathrm{x}$-component of velocity from side

$$
\text { q : } \quad \begin{aligned}
& \text { branch, } \\
& \text { lateral inflow per unit length }
\end{aligned}
$$

$f\left(T_{w}, \phi T D S, \phi I S S\right)$

a density function dependent upon temperature, total dissolved solids or salinity, and inorganic suspended solids.

Some other water quality models are RIVMOD, TOXI, EUTRO, QUAL2E, QUAL-II, SNSIM, SSM, DOSAG -I, DOSAG-3, DOSC1, CE-QUAL-ICM, RMA10, MIKE3, ECOM/RCA and AUTO-QUAL, RIVSC1 etc. are used for the water quality monitoring, management and to simulate variables in river, lake, estuary and ocean water quality.

The Corps model, CE-QUAL-RIV1 (Environmental Laboratory), is a one-dimensional dynamic flow and water quality model used for one-dimensional hydraulic and water quality variations in streams and rivers with highly unsteady flows, although it can also be used to prediction under steady flow conditions. The model resolves longitudinal variations in hydraulic and 
quality characteristics and is applicable where lateral and vertical variations are small. Various hydraulic and water quality models are commonly used for unsteady flow include 1-D dynamic EPA model DYNHYD (Ambrose et al., 1988) are used together with the multidimensional water quality model WASP. DYNHYD solves the one- dimensional equations of continuity and momentum for a branching or channel- junction, computational network.

\section{Ecological models}

Water quality analysis simulation program (WASP): The WASP (Water Quality Analysis Simulation program) model (Ambrose et al., 1988) helps us to interpret and predict water quality responses to natural phenomena and man-made pollution along with pollution management decisions. WASP6 has been developed to aid modelers in the implementation of WASP . WASP6 includes a pre- processor, a rapid processor, and a graphical post- processor that enables the modeler to run WASP more quickly and easily. WASP6 can be applied in one, two, or three dimensions including BOD, dissolved oxygen dynamics, nutrientsleutrophication, bacterial contamination, and toxic chemical movement. It is supplied with two kinetic sub models to simulate two of the major classes of water quality problems: conventional pollution such as BOD, COD, eutrophication and toxic pollution i.e. organic chemicals, metals.

$\frac{\partial}{\partial t}(A C)=\frac{\partial}{\partial x}\left(-U_{x} A C+E_{x} A \frac{\partial C}{\partial x}\right)+A\left(S_{L}+S_{B}\right)+A S_{K}$

Phytoplanktonic specific growth rate:

$$
G_{P I j}=K_{I c} X_{R T j} X_{R I j} X_{R N j}
$$

\section{Light extinction:}

$$
\frac{I_{G k}}{I_{o k}}=\frac{I-\exp \left(-d K_{e} D\right)}{d K_{e} D}
$$

$\mathrm{X}_{\mathrm{RTj}}$ : the temperature adjustment factor, $\mathrm{X}_{\mathrm{RIj}} \quad$ : dimensionless

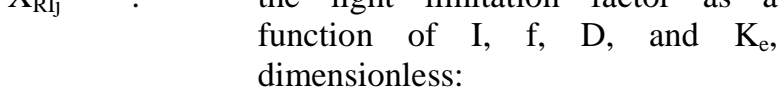

$\mathrm{X}_{\mathrm{RNj}} \quad$ : $\quad$ the nutrient limitation factor as a function of dissolved inorganic phos phorus and nitrogen, dimensionless:

$\mathrm{T} \quad$ : $\quad$ ambient water temperature, ${ }^{\circ} \mathrm{C}$

I : : incident solar radiation, ly/day

f : : fraction day that is daylight, unitless

$\mathrm{K} \quad$ : $\quad$ total light extinction coefficient, $\mathrm{m}^{-1}$

$\mathrm{I}_{\mathrm{ok}} \quad$ : light intensity of wavelength $\mathrm{k}$ just

below water surface,photons $/ \mathrm{cm}^{2}$-sec

$\mathrm{K}_{\mathrm{e}} \quad$ : $\quad$ spatially variable light extinction coefficient, $\mathrm{m}^{-1}$

D : : depth of water segment, $m$

$\mathrm{I}_{\mathrm{Gk}} \quad$ : $\quad$ average light intensity of wavelength $\mathrm{k}$, photons $/ \mathrm{cm}^{2}$-sec

d : ratio of the optical path to the vertical path, $\mathrm{cm} / \mathrm{cm}$
A : cross-sectional area, $\mathrm{m}^{2}$
C : concentration of the water quality constituent, $\mathrm{mg} / \mathrm{L}$ or $\mathrm{g} / \mathrm{m}^{3}$
t : time, days
$\mathrm{Ux}, \mathrm{Uy}, \mathrm{Uz}$ : longitudinal, lateral, and vertical advective velocities, $\mathrm{m}$ /day
Ex,Ey,Ez : longitudinal, lateral, and vertical diffusion coefficients, $\mathrm{m}^{2} /$ day
$\mathrm{S}_{\mathrm{L}} \quad$ : direct and diffuse loading rate, $\mathrm{g} / \mathrm{m}^{3}$-day
$\mathrm{S}_{\mathrm{B}} \quad$ : boundary loading rate (including up stream, downstream, benthic, and atmos pheric), $\mathrm{g} / \mathrm{m}^{3}$-day
$\mathrm{S}_{\mathrm{K}} \quad$ : total kinetic transformation rate

Stream water quality model (QUAL2K): QUAL2K (or $\mathrm{Q} 2 \mathrm{~K}$ ) is one of the most popular one dimension models for river and stream water quality model developed as a modernized version of the QUAL2E model (Brown and Barnwell 1987). Advection, dispersion, dilution, constituent reactions and sources and sinks are all considered within the model. QUAL2K is applicable to well mixed dendritic streams. It can simulate up to 15 water constituents including DO, nutrients simulated internal model, Sediment-water interactions, and Sediment-water fluxes, bottom algae, CBOD.

$$
Q_{i}=Q_{i-1}+Q_{i n, i}-Q_{a b, i}
$$

Qi : outflow from reach $i$ into reach $i+1\left(\mathrm{~m}^{3} / \mathrm{d}\right)$

$Q_{i-l} \quad:$ inflow from the upstream reach $i-1\left(\mathrm{~m}^{3} / \mathrm{d}\right)$

$Q_{i n, i}:$ total inflow into the reach from point and non-point sources $\left(\mathrm{m}^{3} / \mathrm{d}\right)$

$Q a b, i$ : total outflow from the reach due to point and non-point abstractions $\left(\mathrm{m}^{3} / \mathrm{d}\right)$

AQUATOX: The ecosystem model AQUATOX (U.S. Environmental Protection Agency, 2004) is one of the few general ecological risk models that represents the combined environmental fate and effects of toxic organic chemicals. AQUATOX utilizes differential equations to represent changing values of state variables, normally with a reporting time step of one day. It has been designed with the simplest spatial and temporal resolutions consistent with this objective. It can also represent one-dimensional vertical epilimnetic and hypolimnetic conditions for those systems that exhibit stratification on a seasonal basis. AQUATOX uses a very efficient fourth- and fifth-order Runge-Kutta integration routine with adaptive step size to solve the differential equations (Press et al., 1986). The model also represents conventional pollutants, such as nutrients and sediments, and considers several trophic levels, including attached and planktonic algae, submerged aquatic vegetation, several types of invertebrates, and several types of fish. It has been implemented for streams, small rivers, ponds, lakes, and reservoirs.

$$
\frac{\partial C_{i}}{\partial t}+\frac{\partial\left(U C_{i}\right)}{\partial x}+\frac{\partial\left(V C_{i}\right)}{\partial y}+\frac{\partial\left(W C_{i}\right)}{\partial z}=\frac{\partial}{\partial x}\left(D_{x} \frac{\partial C_{i}}{\partial x}\right)+\frac{\partial}{\partial y}\left(D_{y} \frac{\partial C_{i}}{\partial y}\right)+\frac{\partial}{\partial z}\left(D_{z} \frac{\partial C_{i}}{\partial z}\right)+\sum S_{i}
$$

\section{Ammonia:}

$\frac{d \text { Ammonia }}{d t}=$ Loading + Excrete + Decompose - Nitrify - Assimilation $_{\text {Anmonia }}-$ Washout \pm TurbDiff

$\mathrm{d}$ Ammonia/d $t$ change in concentration of ammonia 


\begin{tabular}{|c|c|}
\hline & with time $(\mathrm{g} / \mathrm{n}$ \\
\hline Loading & $\begin{array}{l}\text { loading of nutrient from inflow } \\
\left(\mathrm{g} / \mathrm{m}^{3} \mathrm{~d}\right) ;\end{array}$ \\
\hline Excrete & $\begin{array}{l}\text { ammonia derived from excretion by } \\
\text { animals }\left(\mathrm{g} / \mathrm{m}^{3} \mathrm{~d}\right),\end{array}$ \\
\hline Decompose & $\begin{array}{l}: \text { ammonia derived from decompose- } \\
\text { tion of detritus }\left(\mathrm{g} / \mathrm{m}^{3} \mathrm{~d}\right)\end{array}$ \\
\hline Nitrify & $: \quad$ nitrification $\left(\mathrm{g} / \mathrm{m}^{3} \mathrm{~d}\right)$ \\
\hline Assimilation & $\begin{array}{l}\text { : assimilation of nutrient by plants } \\
\left(\mathrm{g} / \mathrm{m}^{3} \mathrm{~d}\right) \text {, }\end{array}$ \\
\hline Washout & $\begin{array}{l}\text { loss of nutrient due to being carried } \\
\text { downstream }\left(\mathrm{g} / \mathrm{m}^{3} \mathrm{~d}\right)\end{array}$ \\
\hline TurbDiff & $\begin{array}{l}\text { : depth-averaged turbulent diffusion } \\
\text { between e pilimnion and } \\
\text { hypolimnion if stratified }\left(\mathrm{g} / \mathrm{m}^{3} \mathrm{~d}\right),\end{array}$ \\
\hline $\mathrm{U}, \mathrm{V}, \mathrm{W}$ & $\begin{array}{l}\text { : water velocity components in } \\
\text { longitudinal (x), lateral (y) and } \\
\text { vertical }(\mathrm{z}) \text { directions }\end{array}$ \\
\hline & $:$ concentration of the $\mathrm{i}^{\text {th }}$ water quality \\
\hline $\mathrm{D}_{\mathrm{x}}, \mathrm{D}_{\mathrm{y}}$ and $\mathrm{D}_{\mathrm{z}}$ & $\begin{array}{l}\text { diffusion coefficient in } \mathrm{x}, \mathrm{y} \text { and } \mathrm{z} \\
\text { direction }\end{array}$ \\
\hline$\sum S I$ & $\begin{array}{l}: \text { the effective source term, which } \\
\text { includes the kinetic transformation } \\
\text { rate, external loads and sinks for } \mathrm{i}^{\text {th }} \\
\text { water quality constituents }\end{array}$ \\
\hline
\end{tabular}

Air quality modeling: In recent years, urban pollution has emerged as the most acute problem, because of its negative effects on health and deterioration in living conditions. To prevent further exacerbation, a thorough environmental policy is required based on scientific planning of pollution control. With in this framework, it is necessary

To analyze and specify all pollution sources and their contribution to air pollution.

To study the different factors which cause the phenomenon.

To develop tools to reduce pollution by introducing control measures and alternatives to existing practices. The best way of knowing the extent of pollution is to monitor the ground level concentration of pollutants at a number of locations in the city. However, in general, the time and space variations at any place are so great that it becomes very difficult to monitor the pollutants frequently/continuously from both practical and economical point of view. The next alternate to us is to develop a model suitable for application for urban areas.

Now-a -days, atmospheric dispersion model are essential for any air quality management exercise. Air pollution modeling can be viewed as the attempt to predict or simulate, by physical or numerical means the ambient concentration of criteria pollutants found within the atmosphere of a domain. The principle application of air pollution modeling is to investigate air quality scenarios so that the associated environmental impact on a selected area can be predicted and quantified
(Meenakshi and Saseetharan, 2004). A comprehensive air pollution model is able to play an important role in identifying the important factors determining the air quality and wet/dry deposition velocity and furthermore in estimating the fluxes into the region of interests (Park and Cho, 1998). In addition, air quality models can also be used to predict future pollutant concentrations from multiple sources after the implementation of a new regulatory program, in order to estimate the effectiveness of the program in reducing harmful exposures to humans and the environment.

Air quality models use mathematical and numerical techniques to simulate the physical and chemical processes that affect air pollutants as they disperse and react in the atmosphere. Based on inputs of meteorological data and source information like emission rates and stack height, these models are designed to characterize primary pollutants that are emitted directly into the atmosphere and, in some cases, secondary pollutants that are formed as a result of complex chemical reactions within the atmosphere. A comprehensive air quality modeling approach requires the following components:

- Source inventory

- Meteorological data and

- Mathematical algorithm.

Source inventory: An emission inventory is a systematically compiled, expressed and presented set of data on the emission source characteristics allocated with respect to their location and temporal behavior. Studied source characteristics are usually chosen as is required by the dispersion model. It is very important for the inventory to locate and include the main emission sources, as well as the time pattern of their emission. Temporal resolution of one hour and spatial resolution of $1 \mathrm{~km} \times 1 \mathrm{~km}$ are generally selected as the sensitivity level of the inventor. The grid scale should be such that it should contain all the settlements and other activities of interests and should have enough details of the land use. The inventory is based on the chemicals being emitted into the air. The model in use determines the list of the chemicals that are to be studied and also the types of the chemicals determine the types of sources to be included in return (Gupta, 2003). The main anthropogenic sources are mobile sources (road traffic, railway traffic, maritime traffic and air traffic etc.), industrial processes (iron and steel industry, petroleum industry etc.), stationary combustion sources (industrial power plants, domestic boilers etc.) and solvent evaporation (gas stations, domestic point 
application, dry cleaning etc.). Whereas, the main biogenic sources are the hydrocarbon emissions from forests, vegetation and agricultural activities (Costa and Baldasano, 1996).

Meteorological data: Meteorological parameters play an important role in the study of diffusion and advection of air pollutants. The meteorological parameters that affect the pollution concentration at any place can be broadly taken as atmospheric stability, mixing height, wind speed, wind direction and temperature. Wind and temperatures are the basic parameters whereas atmospheric stability and mixing height are the derived parameters.

Wind speed determines the rate of dilution of pollutants and also the time required by them to reach a particular receptor. It also indicates the rapidity with which the pollutants advance into an area. The wind direction is defined, as the direction from which the wind blows, this direction does not remain constant and changes from time to time. Atmospheric stability within the boundary layer has great influence on the motion of air pollutants and thus the turbulent structure of the atmosphere is intimately related to the stability. The atmospheric stability also controls plume rise due to buoyancy and momentum, variation of wind speed with height and diffusion coefficients.

Mathematical algorithm: Mathematical equations of air pollution models describe the process by which pollutants injected into the atmosphere are diluted. At the heart of most every computer program that attempts to relate emissions to air quality is the assumption that the time-averaged pollutant concentration downwind from a source can be modeled using a normal or Gaussian distribution curve. The basic Gaussian dispersion model applies to a single point source such as a smoke stack but it can be modified to account for line source (such as emissions from motor vehicles along a highway) or area sources (one can model these as a large number of point sources).

Point source algorithm: The Gaussian point source dispersion equation relates average steady state pollutant concentrations to the source strength, wind speed, effective stack height and atmospheric conditions.

The contribution to the concentration $(\mathrm{x}, \mathrm{y})$ from a single point source to the receptor at the ground level can be calculated by the following equation (Master, 1995).

$$
C(x, y)=\frac{Q}{\pi u \sigma_{y} \sigma_{z}} \exp \left(\frac{-H^{2}}{2 \sigma_{z}}\right) \exp \left(\frac{-y^{2}}{2 \sigma_{y}}\right)
$$

Where,

\section{$\mathrm{C}(\mathrm{x}, \mathrm{y})$ :}

y :

Q : : emission rate of pollutants $(\mu \mathrm{g} / \mathrm{sec})$

$\mathrm{H} \quad$ : $\quad$ effective stack height (m) $\mathrm{u}$

$\sigma_{\mathrm{y}} \quad:$

Line source algorithm: When a continuous series of point sources moves along a line, as vehicles do along a road, they are equivalent to a continuous line source. If the mean wind direction and the $\mathrm{x}$-axis are perpendicular to the road, then there is no variation of concentration in the y-direction and we have the following equation (Colls, 1997).

$$
C(x, y)=\frac{2 Q}{\sqrt{2 \pi \sigma_{y} \mathrm{u}}}
$$

Where,

$\mathrm{C}(\mathrm{x}, \mathrm{y})$ : concentration at ground level $\left(\mu \mathrm{g} / \mathrm{m}^{3}\right)$

$\mathrm{Q} \quad$ : emission rate per unit of distance along the line $(\mu \mathrm{g} / \mathrm{m} / \mathrm{sec})$

$\mathrm{u} \quad$ : mean wind speed perpendicular to road $(\mathrm{m} / \mathrm{sec})$

$\sigma_{\mathrm{y}} \quad: \quad$ horizontal dispersion coefficient (m)

Area source algorithm: The ground-level concentration at a receptor located downwind of all or a portion of the source area is given by a double integral in the upwind ( $\mathrm{x}$ ) and crosswind (y) directions as (Press, 1986).

$$
X=\frac{Q_{A} K}{2 \pi u_{s}} \int_{x} \frac{V D}{\sigma_{y} \sigma_{z}}\left(\int_{y} \exp \left[-0.5\left(\frac{y}{\sigma_{y}}\right)^{2}\right] d y\right) d x
$$

Where,

$\begin{array}{lll}\mathrm{X} & : & \text { ground level concentration }\left(\mu \mathrm{g} / \mathrm{m}^{3}\right) \\ \mathrm{Q}_{\mathrm{A}} & : & \text { area source emission rate }\left(\mu \mathrm{g} / \mathrm{m}^{2} / \mathrm{sec}\right) \\ \mathrm{K} & : & \text { units scaling coefficient } \\ \mathrm{V} & : & \text { vertical term } \\ \mathrm{D} & : & \text { decay term as a function of } \mathrm{x} \\ \mathrm{y} & : & \text { horizontal distance }(\mathrm{m}) \\ \sigma_{\mathrm{y}} & : & \text { horizontal dispersion coefficient }(\mathrm{m}) \\ \sigma_{\mathrm{z}} & : & \text { vertical dispersion coefficient }(\mathrm{m}) \\ \mathrm{u}_{\mathrm{s}} & : & \text { mean wind speed at source area }(\mathrm{m} / \mathrm{sec})\end{array}$

Air quality models: Gaussian models are often preferred for operational use in EIA studies because they are simple, require limited data and use minimal computational facilities. A number of models had been developed and applied in the past to predict the air quality of different regions around the world (Fisher and Sokhi, 2000; Kitwiroon et al., 2002; Gupta, 2003; Mohan and Siddiqui, 2003). The principle and governing equations of some models has been given below-

Urban diffusion model (Gupta, 2003): Urban diffusion model is a source-oriented model, which uses the steady state Gaussian diffusion plume equations. The model has been developed to predict air quality in the Indian metropolis. Emissions from all types of point sources and area sources have been taken into account in the model.

In order to calculate short term concentration from point sources, the upwind distance $\mathrm{X}$ and the cross- 
wind distance $\mathrm{Y}$ of each source from each receptor are calculated according to the following equations-

$\mathrm{X}=(\mathrm{Sp}-\mathrm{Sr}) \operatorname{Cos} \mathrm{q}+(\mathrm{Rp}-\mathrm{Rr}) \operatorname{Sin} \mathrm{q}$

$\mathrm{Y}=(\mathrm{Sp}-\mathrm{Sr}) \operatorname{Sin} \mathrm{q}-(\mathrm{Rp}-\mathrm{Rr}) \operatorname{Cos} \mathrm{q}$

Where,

$\mathrm{X} \quad$ : upwind distance (m)

$\mathrm{Y} \quad$ : crosswind distance $(\mathrm{m})$

Rp and Sp : E-W and N-S coordinates of point source

$\mathrm{Rr}$ and $\mathrm{Sr} \quad$ : $\quad \mathrm{E}-\mathrm{W}$ and N-S coordinates of receptor $\mathrm{Q} \quad$ : wind direction (the direction from which the wind blows starts from North in the clockwise direction)

The contribution to the concentration $\mathrm{Yp}\left(\mathrm{g} / \mathrm{m}^{3}\right)$ from a single point source to the receptor at the ground level can be calculated by following equations-

(1) For stable conditions or unlimited mixing,

$$
\psi_{p}=\left\{Q /\left(\pi U_{h} \sigma_{y} \sigma_{z}\right)\right\} \cdot \exp \left(-H^{2} / 2 \sigma_{z}^{2}\right) \cdot \exp \left(-Y^{2} / 2 \sigma_{y}^{2}\right)
$$

(2) For unstable or neutral conditions,

$$
\psi_{p}=\left[Q /\left\{(2 \pi)^{1 / 2} U_{h} L \sigma_{y}\right\}\right] \cdot \exp \left(-Y^{2} / 2 \sigma_{y}^{2}\right)
$$

Where,

Yp

Q

$\mathrm{U}_{\mathrm{h}}$

$$
\sigma_{y} \text { and } \sigma_{z}
$$

: pollutant concentration from point source $\left(\mathrm{g} / \mathrm{m}^{3}\right)$

Q : emission rate of the point source (g/sec)

: wind speed $(\mathrm{m} / \mathrm{sec})$ at the top of the stack

\section{standard deviations of plume $\mathrm{X}$ and stability class (m)} concentration distribution in the horizontal and vertical directions as a function of upwind distance

$\mathrm{H} \quad$ : effective plume rise $(\mathrm{m})$

$\mathrm{Y} \quad$ : lateral distance $(\mathrm{m})$

L : mixing depth (m)

To determine the short- term concentration $\psi_{A} \quad\left(\mathrm{~g} / \mathrm{m}^{3}\right)$ from a uniform area source directly upwind of a receptor at the ground, following equations can be used-

(1) For stable conditions or unlimited mixing,

$$
\psi_{A}=\left(Q_{A} / U_{10}\right) \cdot \int_{X 1}^{X 2}\left[\left\{2 \exp \left(-H^{2} / 2 \sigma_{z}^{2}\right)\right\} /\left\{\sigma_{z}(2 \pi)^{1 / 2}\right\}\right] d x
$$

(2) For unstable or neutral conditions,

$$
\psi_{A}=\left(Q_{A} / U_{10}\right) \cdot \int_{X 1}^{X} d x / L
$$

Where,

$\begin{array}{ll}\psi_{A} & : \begin{array}{l}\text { pollutant concentration from area } \\ \text { source }\left(\mathrm{g} / \mathrm{m}^{3}\right)\end{array} \\ \mathrm{Q}_{\mathrm{A}} & : \begin{array}{l}\text { emission rate from the area source } \\ \left(\mathrm{g} / \mathrm{m}^{2} / \mathrm{sec}\right)\end{array} \\ \mathrm{U}_{10} & : \begin{array}{l}\text { wind speed at a height of } 10 \mathrm{~m} \\ (\mathrm{~m} / \mathrm{sec})\end{array} \\ \sigma_{z} & : \text { vertical dispersion coefficient }(\mathrm{m})\end{array}$

$\mathrm{H}$

$\mathrm{L}$

$\mathrm{X}_{1}$

$\mathrm{X}_{2}$

$$
\mathrm{X}_{2}
$$

effective height of area source (m)

mixing depth (m)

distance from the receptor to the locus of upwind ray extending from the receptor to the closest boundary of the area source $(\mathrm{m})$

distance from the receptor to the locus of upwind ray extending from the receptor to the distant boundary of the area source $(\mathrm{m})$

IITAQ model (Mohan and Siddiqui, 2003): IITAQ model is a numerical box model developed for an elevated source that incorporates improved parameterizations of physical processes in the atmospheric boundary layer.

The mathematical equation representing the diffusion of air pollutants released from a source is given by the following diffusion- transport equation-

$$
\frac{\partial C}{\partial t}+u \frac{\partial C}{\partial x}+v \frac{\partial C}{\partial y}+w \frac{\partial C}{\partial z}=\left[K_{x} \frac{\partial C}{\partial x}\right]+\left[K_{y} \frac{\partial C}{\partial y}\right]+\frac{\partial}{\partial z}\left[K_{z} \frac{\partial C}{\partial z}\right]+S+T
$$

Where,

$\begin{array}{ll}\mathrm{C} & : \begin{array}{l}\text { concentration of any given pollutant } \\ \left(\square \mathrm{g} / \mathrm{m}^{3}\right)\end{array} \\ \mathrm{K}_{\mathrm{x}}, \mathrm{K}_{\mathrm{y}}, \mathrm{K}_{\mathrm{z}} \mathrm{:} & \begin{array}{l}\text { eddy diffusivities in } \mathrm{x}, \mathrm{y}, \mathrm{z} \\ \text { directions respectively }\left(\mathrm{m}^{2} / \mathrm{sec}\right)\end{array} \\ \mathrm{u}, \mathrm{v}, \mathrm{w} & : \begin{array}{l}\text { wind components in the } \mathrm{x}, \mathrm{y}, \mathrm{z} \\ \text { directions }(\mathrm{m} / \mathrm{sec})\end{array} \\ \mathrm{S} & : \text { source term } \\ \mathrm{T} & : \text { sink term }\end{array}$

The above equation is reduced into following form-

$$
u \partial C_{t} / \partial_{x}-\partial / \partial_{z} K_{z}\left(\partial C_{t} / \partial_{z}\right)=0
$$

Where,

$\mathrm{C}_{\mathrm{t}} \quad$ : crosswind integrated concentration of the pollutant $\left(\square \mathrm{g} / \mathrm{m}^{3}\right)$

$\mathrm{K}_{\mathrm{z}} \quad$ : turbulent eddy-diffusivity at height $\mathrm{z}$ $\left(\mathrm{m}^{2} / \mathrm{sec}\right)$

$\mathrm{u} \quad$ : wind speed $(\mathrm{m} / \mathrm{sec})$

The above model equation can be used to predict the ambient air concentration of pollutants from elevated as well as ground level sources.

PEARL model (Kitwiroon et al., 2002): The multi box model PEARL (Prediction air quality in urban and regional locations) is based on the following formulation, assuming that the surface roughness is uniform

$$
C=\frac{(2 / \pi)^{1 / 2}(\Delta x / 2)^{1-b}}{U a(1-b)}\left\{Q_{o}+\sum_{i=1}^{N} Q i\left[(2 i+1)^{1-b}-(2 i-1)^{1-b}\right]\right\}
$$

Where,

C

Dx

$\mathrm{U} \quad$ : mean wind speed $(\mathrm{m} / \mathrm{sec})$

Qo : source emission strength for the box

in question ( $\mathrm{m}$ tonne/ $\mathrm{yr} / \mathrm{km}^{2}$ ) $\mathrm{Q}_{\mathrm{i}} \quad$ : source emission strength in the $\mathrm{N}$ surface concentration of the pollutant $\left(\mathrm{mg} / \mathrm{m}^{3}\right)$

: grid spacing or distance across the box $(\mathrm{m})$ 
upwind boxes

i

$\mathrm{a}$ and $\mathrm{b}$
: empirical parameters depending upon the Pasquill- Grifford stability class chosen.

GRAM model (Fisher and Sokhi, 2000): GRAM (University of Greenwich review of air quality model) was developed in UK which include the background concentration for the area through which the road passes as well as the roadside concentrations contributed from vehicles on a road.

Assuming the worst case meteorological conditions (category G), a low wind speed of $1 \mathrm{~m} / \mathrm{s}$ and a low mixing depth of $100 \mathrm{~m}$, the background concentration at the centre of the urban area, $\mathrm{C}_{\text {urban }}$ can be derived from

$$
C_{\text {urban }}=\sqrt{\frac{2}{\pi}} \frac{q}{u} \int_{10}^{d} \frac{d x}{\sigma_{z}(x)}
$$

Where,

$$
\begin{array}{ll}
\mathrm{C}_{\text {urban }} & : \begin{array}{l}
\text { concentration at center of the urban } \\
\text { area }(\mathrm{ppm})
\end{array} \\
\mathrm{S}_{\mathrm{z}}(\mathrm{x}) & : \text { vertical dispersion }(\mathrm{m}) \\
\mathrm{q} & : \text { emission density }\left(\mathrm{kt} / \mathrm{km}^{2} / \mathrm{yr}\right) \\
\mathrm{d} & : \text { distance }(\mathrm{km}) \\
\mathrm{u} & : \text { wind speed }(\mathrm{m} / \mathrm{sec})
\end{array}
$$

Assuming the wind direction is across the road, the contribution from vehicles on a road to the concentration in the vicinity $\mathrm{C}_{\text {road }}$ is given by

$$
C_{\text {road }}=\sqrt{\frac{2}{\pi} \frac{Q}{u}} \frac{1}{\sigma_{z}(x)}
$$

Where,

$$
\begin{array}{ll}
\mathrm{C}_{\text {road }} & : \begin{array}{l}
\text { concentration in the vicinity of road } \\
\left(\mathrm{g} / \mathrm{m}^{3}\right)
\end{array} \\
\mathrm{Q} & \begin{array}{l}
: \text { emission strength per unit length of } \\
\text { road }(\mathrm{g} / \mathrm{m} / \mathrm{sec})
\end{array} \\
\mathrm{S}_{\mathrm{z}}(\mathrm{x}) & : \text { vertical dispersion }(\mathrm{m}) \\
\mathrm{u} & : \text { wind speed }(\mathrm{m} / \mathrm{sec})
\end{array}
$$

UGEM model (Murphy- Klimova et al., 1998): The air pollution transport model UGEM (The University of Greenwich evaluation model) has been developed to evaluate medium- range transport and deposition of sulphur and oxidized nitrogen from all types of sources of emissions in the UK and to estimate their average annual deposition and concentration across the UK.

UGEM is a receptor- oriented, lagrangian type model, which yields annual average concentrations and depositions of $\mathrm{SO}_{2}, \mathrm{SO}_{4}, \mathrm{NO}_{2}, \mathrm{NO}_{3}$ and $\mathrm{HNO}_{3}$ across the UK. UGEM provides a method for simulating atmospheric transport and dispersion using air parcels that follow the wind flow. According to the model, the concentration $\mathrm{C}^{\mathrm{l}}$ of pollutant ' $\mathrm{l}$ ' along air mass trajectories weighted according to wind direction is given as-

$$
\frac{d C^{l}}{d t}=-\left(\frac{v_{d}^{l}}{h}+k_{w}^{l} P+k_{c}^{m, l}-k_{c}^{l, m}\right) \times C_{o}^{l}
$$

Where,

$$
\begin{array}{lll}
C^{l} & : \text { concentration of pollutant }\left(\square \mathrm{g} / \mathrm{m}^{3}\right) \\
k_{w}^{l} & : & \text { wet scavenging ratio } \\
v_{d}^{l} & : & \text { dry deposition velocity }(\mathrm{mm} / \mathrm{sec}) \\
k_{c}^{l, m} & & \\
& & \text { chemical conversion rates from } \\
& & \text { pollutant } 1 \text { to pollutant } \mathrm{m}(\mathrm{per} \mathrm{sec}) \\
k_{c}^{m, l} & : & \text { chemical conversion rates from } \\
& & \text { pollutant m to pollutant } 1(\mathrm{per} \mathrm{sec}) \\
\mathrm{P} & : & \text { annual level of precipitation }(\mathrm{mm} / \mathrm{yr}) \\
\mathrm{h} & : & \text { height of the mixing layer }(\mathrm{m})
\end{array}
$$

EMITEMA- EIM model (Costa and Baldasano, 1996): EMITEMA- EIM model is an atmospheric emission model developed to compute and display the emissions interactively. The model considered the three kinds of emissions from road traffic- hot emissions, cold start emissions and evaporative emissions.

To compute the total traffic emissions of pollutant ' $i$ ' in a stretch of a roadway ' $r$ ' of type ' $p$ ' of length $L_{r}$ per $\mathrm{km}^{2}$ per hour, the hot emissions, cold start emissions and the evaporative emissions are summed up and multiply by the monthly fluctuation $(\mathrm{m})$, by the daily fluctuation (d) and by the hourly variation (h).

$$
E_{r}^{i T}\left(g / k m^{2} h\right)=\left(E_{r}^{i h o t}+E_{r}^{i c o l d}+E_{r}^{i e v a p}\right) x\left(g / k m^{2} d\right) m d h
$$

Where,

$$
\begin{array}{lll}
\mathrm{E}_{\mathrm{r}}^{\mathrm{iT}} & : & \text { total traffic emission } \\
\mathrm{E}_{\mathrm{r}} \text { ihot } & : & \text { total hot emission } \\
\mathrm{E}_{\mathrm{r}}^{\text {icold }} & : & \text { total cold start emission } \\
\mathrm{E}_{\mathrm{r}}^{\text {ievap }} & : & \text { total evaporative emission } \\
\mathrm{m} & : & \text { monthly fluctuations } \\
\mathrm{d} & : & \text { daily fluctuations } \\
\mathrm{h} & : & \text { hourly fluctuations } \\
\mathrm{r} & : & \text { roadway of } \mathrm{p} \text { type (street, road or } \\
& & \text { highway) }
\end{array}
$$

IITLT model (Goyal et al., 1994): IITLT model is a Gaussian plume model developed at IIT Delhi, India and has been used to estimate long- term concentrations of non- reactive pollutants due to emissions from area and point sources. The IITLT model is designed to treat calm wind conditions $(\mathrm{u}<2 \mathrm{~m} / \mathrm{sec})$. The ground - level concentration at each receptor due to area sources is given by-

$$
C=\sum_{j} C_{j}=\frac{\sqrt{2 / \pi}}{a(1-b) u} Q_{j}\left(X_{j+1}^{i-b}-X_{j}^{i-b}\right)
$$

Where,

$$
\begin{array}{ll}
\mathrm{C}_{\mathrm{j}} & : \begin{array}{l}
\text { concentration due to area source } \\
\left(\mathrm{g} / \mathrm{m}^{3}\right)
\end{array} \\
\mathrm{Q}_{\mathrm{j}} & : \text { source strength }\left(\mathrm{g} / \mathrm{m}^{2} / \mathrm{sec}\right) \\
\mathrm{j} & : \text { upwind grid } \\
\mathrm{X}_{\mathrm{j}} \text { and } \mathrm{X}_{\mathrm{j}+1}: & \begin{array}{l}
\text { upwind distance between } \mathrm{j}^{\text {th }} \text { and } \\
(\mathrm{j}+1)^{\text {th }} \text { grid }(\mathrm{m})
\end{array} \\
\mathrm{a} \text { and } \mathrm{b} & : \text { stability parameters }
\end{array}
$$


$\mathrm{u} \quad: \quad$ mean wind speed $(\mathrm{m} / \mathrm{sec})$

For the elevated point sources, the concentration $C_{p}$ at different receptor points is

$$
C_{p}=\frac{360 f Q}{\sqrt{2 \varphi \pi^{3 / 2} u \times \sigma_{z e}}} \mathrm{exp}\left(-\frac{h^{2}}{2 \sigma_{z e}^{2}}\right)
$$

Where,

$\mathrm{C}_{\mathrm{p}} \quad: \quad$ concentration due to elevated point source $\left(\mathrm{g} / \mathrm{m}^{3}\right)$

Q : emission strength of point source $(\mathrm{g} / \mathrm{sec})$

$\mathrm{f} \quad$ : angular width of direction sector (in degrees)

f : percentage frequency of occurrence of winds in a particular direction, wind group and stability during the period of interest

$\mathrm{u} \quad: \quad$ mean wind speed $(\mathrm{m} / \mathrm{sec})$

$\mathrm{h} \quad: \quad$ effective stack height $(\mathrm{m})$

$\mathrm{x} \quad$ : distance downwind $(\mathrm{m})$

$\mathrm{S}_{\mathrm{ze}} \quad:$ vertical dispersion parameter for an elevated source $(\mathrm{m})$

The total concentration at any receptor point is calculated as $\mathrm{C}+\mathrm{C}_{\mathrm{p}}$

Model for traffic emissions (Alexopoulos et al., 1993): A model was developed by Alexopoulos et al. (1993) for the spatial and temporal evaluation of traffic emissions in metropolitan areas based on sparse measurements. The model is flexible and allows for the estimation of distributed small traffic sources (non- line/ area sources).

In the model, the arteries for which traffic data exist are divided into small linear segments. These, in turn are considered as independent line sources with constant traffic variables. Under these assumptions, the pollutant quantity $E_{p}$ emitted from a segment of an artery (hence line source) of length ' $l$ ' during a time period ' $t$ ' is given by

$$
E_{p}=\sum_{i=1}^{N} Q . \sigma_{i} \cdot l \cdot \ell_{p i}
$$

Where,

$\begin{array}{ll}\mathrm{E}_{\mathrm{p}} & : \begin{array}{l}\text { pollutant quantity }(\mathrm{kg} / \mathrm{km} / \mathrm{hr}) \\ 1\end{array} \\ \mathrm{Q} . \mathrm{s}_{\mathrm{i}} & : \begin{array}{l}\text { length of segment of artery }(\mathrm{km}) \\ \text { traffic load of vehicles of category } \\ \text { 'i' in the time period studied } \\ \text { (number of vehicles/ } \mathrm{km} / \mathrm{hr})\end{array} \\ \ell_{p i} & : \text { emission factor }(\mathrm{kg} / \mathrm{km})\end{array}$

\section{Conclusion}

Modeling provides a variety of tools with which one can conduct numerical experiments, test hypothesis and understand system dynamics. When comparing the various advantages /disadvantages and apparent implications of differences in structures and assumptions of various models, it is important to recognize that each model is an extremely crude representation of complex system behavior based on an incomplete understanding of the system. It results in an increase in fundamental knowledge due to its involvement in considerable analysis of the system. Besides, these models are helpful to interpret and predict environmental quality responses to natural/ anthropogenic pollution and its management decisions. Similarly, a modeling approach can result in considerable saving in both time and money.

\section{REFERENCES}

Alexopoulos, A., Assimacopoulos, D. and Mitsoulis, E. (1993). Model for Traffic Emissions estimation. Atm. Env., 27 B: 435-446.

Ambrose, R. B., Wool, T., Connolly, J. P. and Schanz, R. W. (1988). WASP4, A Hydrodynamic and Water Quality Model: Model Theory, User's Manual, and Programmer's Guide. Envir. Res. Lab., EPA 600/3-87/039, Athens, GA.

Boler, R. (1992). Surface water quality. Hillsborough County, Florida, pp. A-2.

Cerco, C. F. and Cole, T. (1993). Three-dimensional eutrophication model of Chesapeake Bay. J. Envir. Eng., 119:1006-1025.

Chapman, D. (1992). Water quality assessment, ed. D. Chapman, pp.585. Chapman \& Hall, London.

Chapra, S. C. (1997). Surface water quality modeling. New York, McGraw-Hill.

Cole, R. W. and Buchak, E. M. (1995). CE-QUAL-W2V3: A two-dimensional, laterally averaged, hydrodynamic and water quality model. Version 3.0. Instructional Rep. EL -95-1, U.S. Army Engineer Waterways Experiment Station, Vicksburg, Miss. pp 609.

Colls, J. (1997). Air pollution - An Introduction, E\&FN Spon and U.K.

Conesa Fdez-Vitora, V. (1995). In: Methodological guide for environmental impact evaluation (Guia Metodologica para la Evaluacion del Impacto Ambiental), $2^{\text {nd }}$ ed.,pp 390. Mundi-prensa, Madrid.

Costa, M. and Baldasano, J. M. (1996). Development of a source emission model for atmospheric pollutants in the Barcelona area. Atm. Env., 30: 309-318.

Fisher, B.E.A. and Sokhi, R.S. (2000). Investigation of road side concentrations in busy streets using the model GRAM: conditions leading to high short term concentration. Int. Jr. Env. \& Poll., 14: 488-495.

Gin, K. Y. H., Zhang, Q. Y., Chan, E. S. and Chou, L. M. (2001). Three-dimensional ecological eutrophication model for Singapore. J. Envir. Eng., 127: 928-937.

Goyal, P., Singh, M. P. and Bandyopadhyay, T. K. (1994). Environmental studies of $\mathrm{SO}_{2}, \mathrm{SPM}$ and $\mathrm{NO}_{\mathrm{x}}$ over Agra with various methods of treating calms. Atm. Env., 28: 3113-3123.

Gupta, R. N. (2003). An urban diffusion model for a metropolis. Indian J. Air Poll. Con., 3: 1-19.

Jin, K. R., James, R. T., Lung,W. S., Loucks, D. P., Park, R. A. and Tisdale, T. S. (1998). Assessing lake Okeechobee eutrophication with water-quality models. J. Water Resour. Plng. Mgmt., 124:22-30.

King, I. P. (1990). Program documentation RMA-2V. Two dimensional finite element model for flow in Estuaries and Streams, Version 4.3, Resource Management Associates. Lafayette. CA

Kitwiroon, N., Sokhi, R. S., Luhana, L. and Teeuw, R. M. (2002). Improvements in air quality modeling by using surface boundary layer parameters derived from satellite 
land cover data. Water, Air and Soil Pollution, 2: 29-41.

Kuzmin, D. (2010). A guide to numerical methods for transport equations. Friedrich Alexander Universitat Erlangen Nurnberg.

Lawrence, A. B. (2004). U.S. Environmental Protection Agency (EXAM) 960 college station road Athens, Georgia 30605-2700 EPA/600/R!00/081 2000 Revision G.

Master, G. M. (1995). In: Introduction to environmental engineering and sciences. Prentice-Hall, Inc, New Delhi.

Meenakshi, P. and Saseetharan, M. K. (2004). A Urban air pollution forecasting with respect to SPM using time series neural networks modelling approach- a case study in Coimbatore city. J. Env. Sci. \& Engg., 46: 92-101.

Mohan, M. and Siddiqui, T. A. (2003). Development of an air quality prediction model for an elevated release during convective conditions. Indian J. Air Poll. Cont., 3: $19-30$.

Murphy-Klimova, E, Fisher, B.E.A. and Sokhi, R. S. (1998). Treatment of urban areas within a regional transport model of sulphur and nitrogen oxides. Env. Mon. \& Assess., 52: 213 - 224.

Park, J. and Cho, S. Y. (1998). A long range transport of $\mathrm{SO}_{2}$ and Sulphate between Korea and East China. Atm. Env., 32 (16): 2745-2756.

Park, R. A., Clough, S. J. and Wellman, M. C. (2004). Modeling environmental fate and ecological effects in aquatic ecosystems (AQUATOX-2).User's Manual, Volume-1. US environmental protection agency office of water. Washington DC 20460.

Patankar, S. V. (1980). Numerical heat transfer and fluid flow. McGraw Hill. New York

Press, W. H., Flannery, B. P., Teukolsky, S. A. and Vetterling, W. T. (1986). Numerical Recipes: The Art of Scientific Computing. Cambridge University Press, Cambridge, U.K., pp. 818 .

Reynolds, C. S. (1984). The ecology of freshwater phytoplankton. Cambridge University Press. Cambridge. U.K

Thomann, R. V. and Mueller, J. A. (1988). Principles of surface water quality modeling and control, Harper \& Row Publication, New York.

USEPA (2004). Modeling environmental fate and ecological effects in aquatic ecosystems. Vol. 1: User manual Ed. By Richard A. Park, Jonathan S. Clough, and Marjorie Coombs Wellman. United State Environmental Protection Agency, Washington DC 20460.

Versteeg, H. and Malalasekera, W. (1995). An introduction to computational fluid dynamics- the finite volume method, Longman, London.

Wainwright, J. and Mulligan, M. (2004). Environmental modelling finding simplicity in complexity. John Wiley \& Sons Ltd.

Wood, W. L. and Arnold, P. D. (1990). On the box scheme for overland flow calculation. Communications in Applied Numerical Methods, 6(4): 323-325. 